\title{
EVIDENCE OF A PERIODIC ICE-CLIFF AVALANCHE ON NORTH-WEST ELLESMERE ISLAND, N.W.T., CANADIAN HIGH ARCTIC
}

\author{
By D.J.A. EvANS and T.G. FISHER
}

(Department of Geography, University of Alberta, Edmonton, Alberta T6G 2H4, Canada)

\begin{abstract}
Evidence of a recent (1985) ice-cliff avalanche from an outlet lobe of a small plateau ice cap on north-west Ellesmere Island is discussed. Former avalanche events are evidenced by debris lying outside the 1985 avalanche material. Periodic activity seems to be linked to the build-up of melt water in the crevasses of the outlet lobe during the melt season. The exact magnitude and frequency of events are unknown. Some implications to geomorphology and the sedimentology of sub-polar glaciers are discussed.
\end{abstract}

\section{INTRODUCTION}

Observations on the polar and sub-polar glaciers of the Arctic continue to provide insights into the behaviour of these high-latitude ice masses. This note presents such an observation from Phillips Inlet, situated at lat. $82^{\circ} \mathrm{N}$. on north-west Ellesmere Island, N.W.T., Canada. At this location, ice covers approximately $50 \%$ of a $2300 \mathrm{~km}^{2}$ field area (Fig. 1). Ice bodies in this area are grouped into three categories: cirque glaciers, plateau ice caps with outlet lobes, and transection glaciers. Glaciers of all three categories debouch into fiords or the main Arctic Ocean at several locations.

This note refers to an outlet lobe of a plateau ice cap, unofficially named the "Aviator Ice Cap".* The ice cap is approximately $12 \mathrm{~km}^{2}$ in area and lies between $460 \mathrm{~m}$ and $1070 \mathrm{~m}$ in altitude. The outlet lobe is approximately $900 \mathrm{~m}$ wide and drains the ice cap southward. The lobe is truncated by an ice cliff where the local slope steepens into the head of a narrow tributary valley of Storm River (Figs 1 and 2). The tributary valley is $3.5 \mathrm{~km}$ long and is a major melt-water drainage course from the Aviator Ice Cap.

\section{THE ICE AVALANCHE}

\section{Observations}

Air photographs from 1959 reveal a prominent trim line and surface-weathering break within the tributary valley (Fig. 2). This weathering break extends approximately $3 \mathrm{~km}$ down-valley from the ice cliff where it ends at a bedrock constriction. The surface of the outlet lobe immediately above the ice cliff displays severe crevassing.

Upon visiting the site in the summer of 1985, we discovered that the valley bottom, in the area between 1 and $2 \mathrm{~km}$ from the ice cliff, contained a lobate body of fallen ice blocks of various sizes and large amounts of debris (Fig. 3). The altitudes of the ice cliff and the lobate front are approximately $760 \mathrm{~m}$ and $305 \mathrm{~m}$, respectively. A debris-clean zone existed from the ice cliff to $1 \mathrm{~km}$ down-valley. High melt-water discharge was being generated by the melting ice blocks and streams were exiting from within and beneath the lobe (Fig. 4). Some melt water was also being provided by natural drainage from the ice cap. Large levees built

*All names are unofficial other than Phillips Inlet. with ice blocks (in places exceeding $5 \mathrm{~m}^{3}$ ) and considerable debris existed along the length of the feature (Fig. 3). The trim line from the 1959 air photograph is defined on the ground by subdued levees immediately above the 1985 levées. The lighter tone, representing lichen and vegetationfree material, is a result of periodic coverage by avalanche debris and is similar in appearance to the products of retreating perennial snow and ice patches.

Beyond the down-valley limit of the 1985 lobe, evidence of earlier events exists in: (1) well-preserved but subdued levées of debris and (2) a considerable thickness of debris, approximately $20 \mathrm{~m}$, on the floor of the valley which has been exposed by stream dissection (Fig. 5). A very approximate maximum estimate for avalanche volume would be in the order of $10^{7} \mathrm{~m}^{3}$. In places this debris is ice-cored due to the incomplete melt-out of previous ice blocks. It is pertinent to note here that no debris appears to be entrained at the ice cliff.

\section{Interpretation}

The lobate cover of ice blocks and debris with its marginal levees is interpreted as an avalanche from the ice cliff of the Aviator Ice Cap. The "run-out distance" (Alean, 1984) of the 1985 event was $2 \mathrm{~km}$ and this was 4.5 times longer than the overall vertical drop. Because the tributary valley is a major conduit for melt water draining the ice cap, the initiation of such an avalanche is thought to be related to the filling of the crevasses above the ice cliff by the melt water. Large amounts of supraglacial melt water are observed on glaciers throughout northern Ellesmere Island and deep crevasses filled with melt water have been observed in Phillips Inlet. The formation of crevasses at the surface of the Aviator Ice Cap is related to the oversteepening of the underlying topography and associated extending flow. Filling of these crevasses with melt water creates instability and failure at the ice cliff, and an avalanche of ice blocks cascades down the valley possibly riding on a cushion of air and water.* The avalanche material came to rest between 1 and $2 \mathrm{~km}$ from the ice cliff. The lobate front of the feature and its levees facilitate a form analogous with a large slush avalanche which, in this case, is confined by a small valley (Nyberg, 1985; Onesti, 1986). ${ }^{\dagger}$ Approximately $80 \%$ of the transported material is ice and very little evidence of any one avalanche event persists from one year to the next. A succession of

*The role of air as a friction reducer in landslides and ice avalanches was questioned by Alean (1984). In a personal communication, Alean has also suggested that water lubrication be dropped as a friction-reducing factor unless the amount of water is comparable to the ice volume released. This is a valid observation but, because we have no estimate of the volume of melt water in the crevasse systems of the ice body, we do not feel that we can reject the water-lubrication hypothesis at this time.

${ }^{\dagger}$ For a general discussion of slush avalanching, see Embleton and King (1975, p. 149-51). 


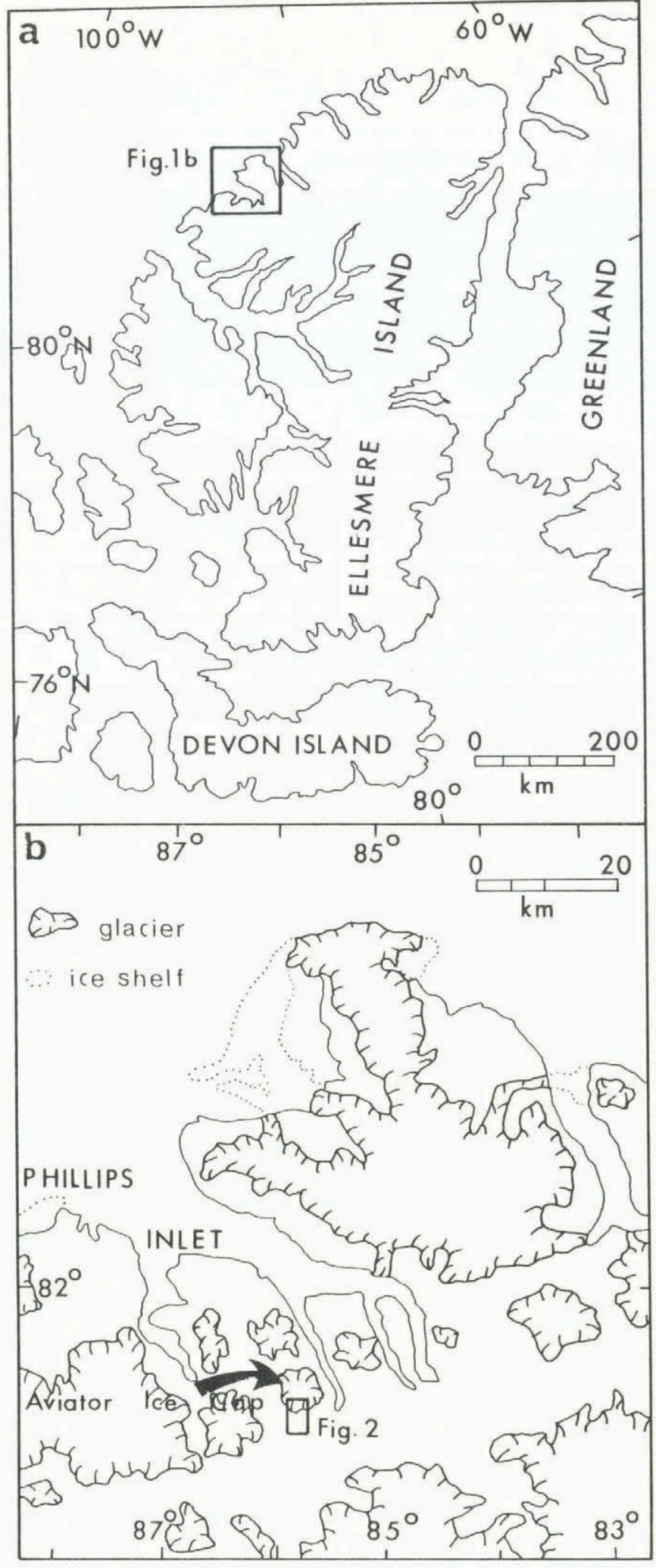

Fig. 1. $a$ and $b$. Location of Ellesmere Island, Phillips Inlet, and the "Aviator Ice Cap".

periodic events of similar magnitude would conceivably change the long profile of the valley by incremental deposition of debris. For example, Rapp (1959, 1960) suggested that slush avalanching can carry approximately ten times as much rock debris as other avalanche types.

The trim line or weathering break from the 1959 air photograph (recognized as subdued levées in 1985), together with evidence of older lobate forms and debris outside the 1985 avalanche lobe (Fig. 5), suggest that the event is

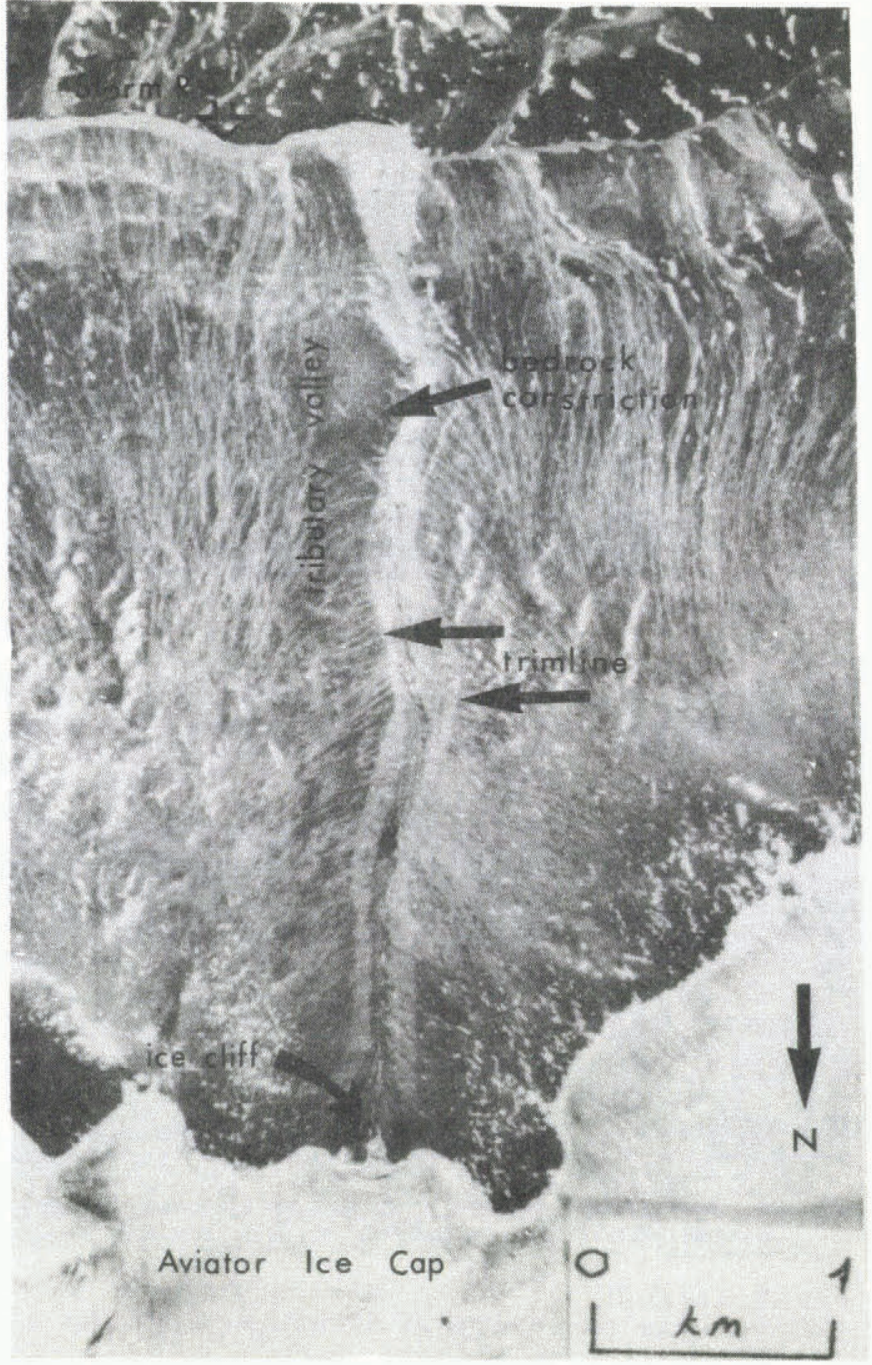

Fig. 2. Section of air photograph A-16605-84 illustrating the crevassed outlet lobe from the Aviator Ice Cap and prominent trim line as of August 1959. (Air photograph A-16605-84 by Department of Energy, Mines and Resources, Canada.)

recurrent. However, because evidence of smaller events would be obliterated and there is no direct dating control, the exact magnitude and frequency of the avalanching are unknown. In this case, each avalanche event may be linked to the melt season. The 1985 event had occurred since the last major snowfall because the winter snow cover in the path of the avalanche had been removed.

The most recent work on ice avalanches is by Alean (1984, 1985), in the European Alps. Although Alean included "cold-based" glaciers in his reports, he is essentially concerned with Alpine hanging glaciers where annual snow/ ice accumulation is greater and bedrock profile changes are generally more abrupt. However, his general classification scheme of avalanche "starting zones" (Alean, 1985) is pertinent here. Starting-zone type I is on uniformly inclined bedrock and can be subdivided into types IA and IB. Little or no ice is frozen to the bedrock in IA, whereas most ice is frozen to bedrock in IB. Starting-zone type II occurs where there is an abrupt longitudinal change in bedrock profile. Avalanching from a type II zone is related to slab or serac release and is generally of a smaller magnitude than a type I avalanche. Alean also stated that avalanches from IA starting zones have a clear seasonal distribution and this is linked to late spring/early summer melt. This is obviously important in glaciers which are not entirely frozen to bedrock. For example, Alean recorded ice avalanches from type IB starting zones in all seasons.

The ice avalanche at the Aviator Ice Cap does not 


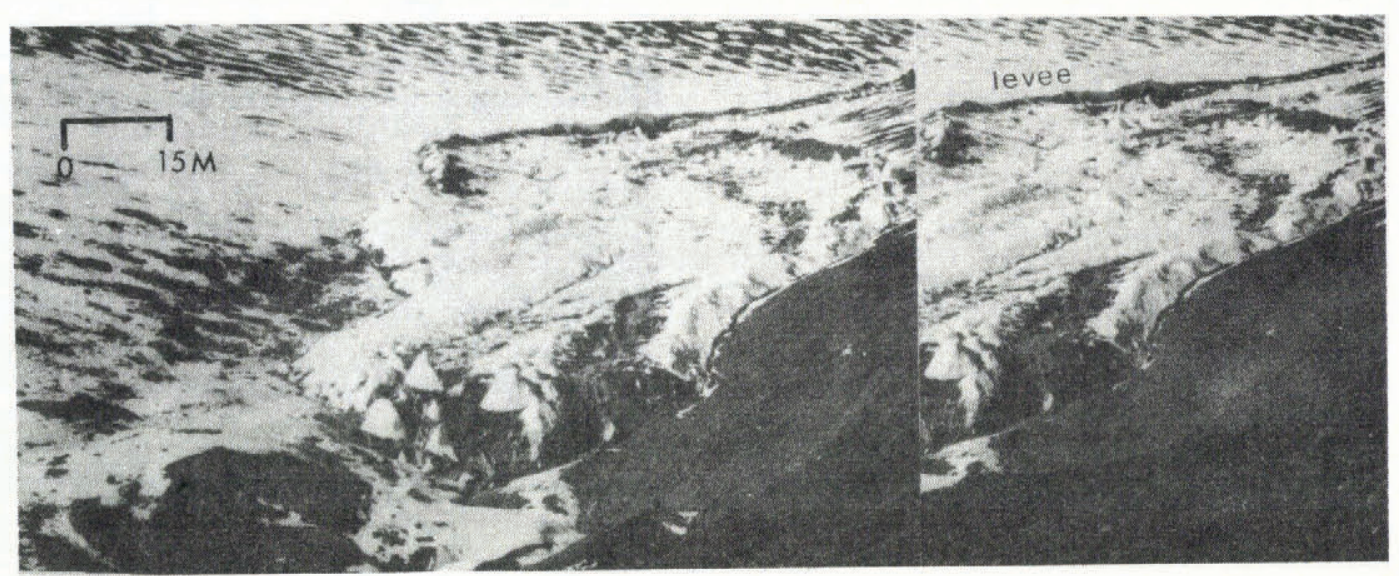

Fig. 3. Stereopair of the debris lobe in the tributary valley bottom as at 28 June 1985.

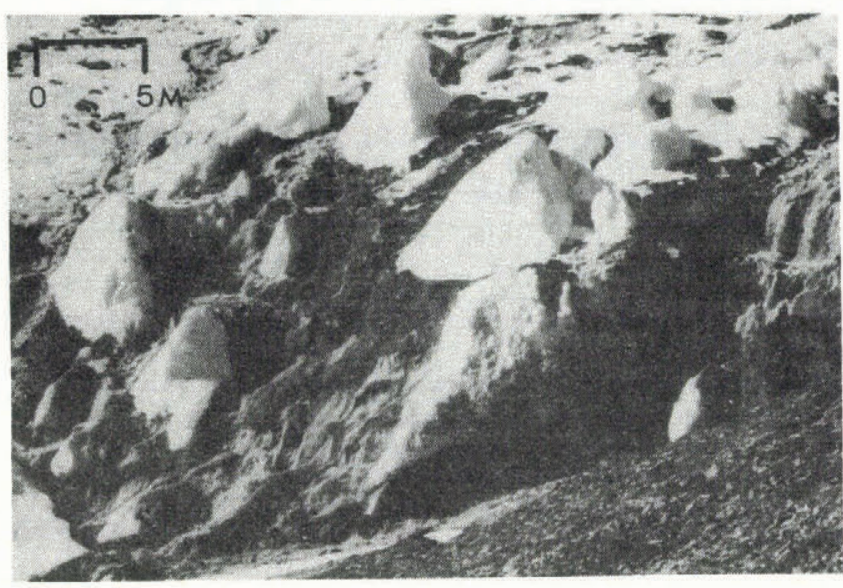

Fig. 4. Telephotograph of the ice- and debris-lobe front illustrating the concentration of debris and the emission of melt water.

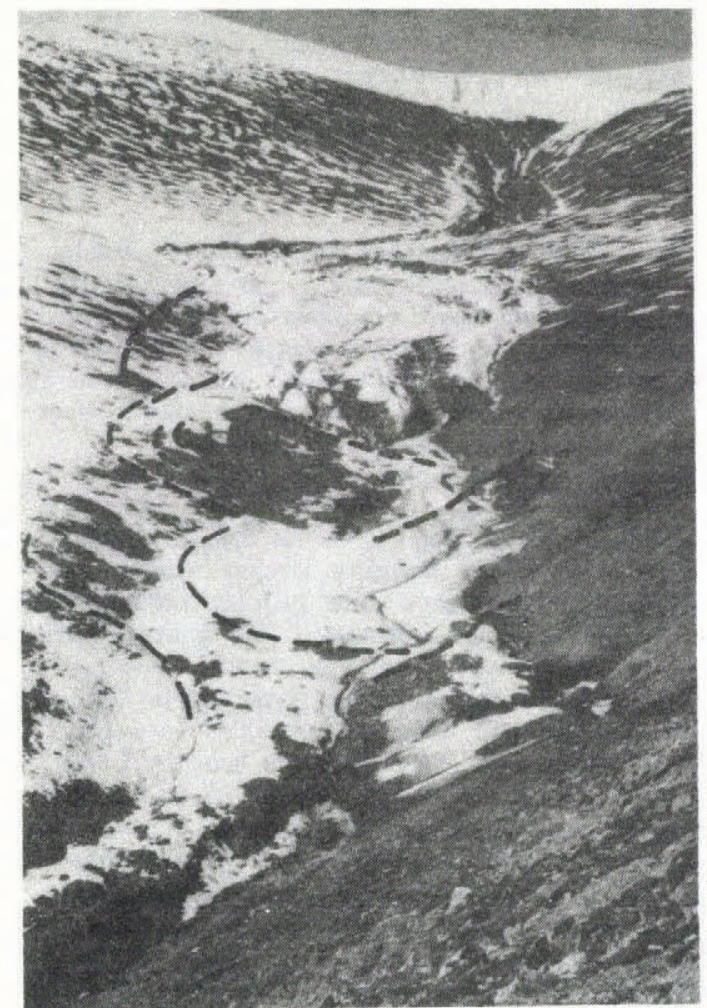

Fig. 5. Dissected debris lobes beyond the 1985 avalanche attesting to former avalanche events. Also visible is the debris and ice-clean zone below the ice cliff and large levees delineating the boundary of the avalanche material. appear to comply with Alean's scheme. A longitudinal change in bedrock profile, together with its frozen-bed characteristics, would enter the Aviator Ice Cap avalanche into either a type II or a IB classification, respectively. Furthermore, if the avalanching occurs during spring/early summer in the High Arctic, due to a high supraglacial melt-water discharge at that time, it would be uncharacteristic of Alean's type II or IB.

Because this note is based on only one ice-cliff avalanche compared to the 13 individual glaciers studied by Alean, comparisons between the two field areas are largely inappropriate. Topographic, climatic, and glaciological differences must be taken into account in any long-term comparative analysis. It is important to note, however, that Alean cited internal mechanical failure as the dominant release mechanism in type II and IB starting zones. This also appears to be the dominant release mechanism at the ice cliff of the Aviator Ice Cap, where melt water in the crevasse systems could push off mechanically unstable lamellae. Furthermore, there is no direct evidence that pre1985 avalanches occurred in the spring/summer, so a type II starting zone is provisionally the most appropriate classification in this case.

\section{IMPLICATIONS TO GEOMORPHOLOGY AND SEDI- MENTOLOGY}

It is apparent that an "intrinsic threshold" (Schumm, 1973) exists at the ice cliff of the Aviator Ice Cap. This was defined by Schumm: "... a progressive change in the system itself renders it unstable and failure occurs". A dramatic response in the glacier system is produced by the exceeding of a major threshold. This involves both the build-up of ice above the oversteepened valley head and the filling of the resultant crevasses by melt water. The effect is instability and avalanching. Normal dry calving from the ice cliff may occur during periods of stability.

Because the valley headwall is a major component of this cycle of events, it would follow that during glacierization an increased rate of flow over the cliff would lead to and accelerate the occurrence of avalanching. At some point, the ice-choked valley would stabilize the system and the ice lobe would advance and incorporate the debris. Similarly, any retreat of the ice lobe from its present position would terminate the avalanching.

Many plateau ice caps similar to the Aviator Ice Cap exist on northern Ellesmere Island and lobes emanating from these ice caps debouch into the sea. During the last glaciation, glaciers were restricted, in many cases, to only a few kilometers beyond their present margins where they contacted a higher sea-level (England, 1983; Bednarski, unpublished). Because of this restricted glacial style and a sparsity of moraines, the mapping of the last glacial ice limit relies heavily upon the interpretation of glacio-marine sediments. Clearly, if ice avalanches occurred in more than locality, then sedimentary sequences might record such events.

A further implication relates to the incorporation of debris by polar glaciers. As is noted above, the ice cliff 
reveals a negligible entrainment of debris by the outlet ice lobe. Shaw (1977[a], [b]) interpreted basal debris in Antarctic glaciers as over-ridden ice-frontal aprons. The over-riding of ice avalanches by an advancing glacier would likely produce similar entrainment patterns. The amount of debris available for entrainment in this manner would depend on the erosive capabilities of each avalanche event. For example, more material would be disturbed by the avalanche if it occurred late in the spring, because there would be a thicker active layer from which material could be derived. This ties in with the above reference to Rapp's $(1959,1960)$ calculation of the amount of debris carried by avalanching. However, the amount of debris involved in this case is unknown.

If avalanching at the Aviator Ice Cap is entirely or partly dependent on melt-water build-up in crevasses, then the threshold would likely be exceeded during the melt season. In this particular case study, the avalanche occurred prior to 28 June when local snow cover was still greater than $60 \%$. We are unable to determine whether or not this event is annual of whether instability is attained after several years.

There are several plateau ice caps in the Phillips Inlet area and their outlet lobes of ten terminate as ice cliffs similar to that of the Aviator Ice Cap. Consequently, it would be reasonable to assume that such ice avalanches as the one described here could have a significant role in glacial debris entrainment in the area. Finally, it must be stressed that melt water plays a prominent role in glacial debris entrainment and ice dynamics in Phillips Inlet and has certainly been greatly underestimated in past research on high-latitude ice masses. Further work in this High Arctic fiord landscape will address the role of melt water in the polar glacier system.

\section{ACKNOWLEDGEMENTS}

Field work in Phillips Inlet during the summer of 1985 was made possible by logistical and financial support from the Polar Continental Shelf Project, Department of Energy, Mines and Resources, Ottawa, and the Boreal Institute of Northern Studies at the University of Alberta, respectively. An NSERC (Natural Science and Engineering Research Council) award to T.G. Fisher is also gratefully acknowledged. Comments on the original manuscript by $\mathrm{J}$. Alean and an anonymous referee are appreciated. F. Metcalfe, Department of Geography, University of Alberta, typed the manuscript.

\section{REFERENCES}

Alean, J. 1984. Ice avalanches and a landslide on Grosser Aletschgletscher. Zeitschrift für Gletscherkunde und Glazialgeologie, Bd. 20, p. 9-25.

Alean, J. 1985. Ice avalanches: some empirical information about their formation and reach. Journal of Glaciology, Vol. 31, No. 109, p. 324-33.

Bednarski, J. Unpublished. Glacier fluctuations and sea level history of Clements Markham Inlet, northern Ellesmere Island. [Ph.D. thesis, University of Alberta, 1984.]

Embleton, C., and King, C.A.M. 1975. Periglacial geomorphology. London, Edward Arnold.

England, J. 1983. Isostatic adjustments in a full glacial sea. Canadian Journal of Earth Sciences, Vol. 20, No. 6, p. 895-917.

Nyberg, R. 1985. Debris flows and slush avalanches in north Swedish Lappland. Lunds Universitets Geografiska Institution. Meddelanden, Nr. 97.

Onesti, L.J. 1986. Slush avalanche characteristics: some observations. (In 15th Annual Arctic Workshop, April 24-26, 1986. Boulder, CO, INSTAAR [Institute of Arctic and Alpine Research], p. 55.)

Rapp, A. 1959. Avalanche boulder tongues in Lappland; descriptions of little-known forms of periglacial debris accumulations. Geografiska Annaler, Vol. 41, No. 1, p. 34-48.

Rapp, A. 1960. Recent development of mountain slopes in Kärkevagge and surroundings, northern Scandinavia. Geografiska Annaler, Vol. 42, Nos. 2-3, p. 65-200.

Schumm, S.A. 1973. Geomorphic thresholds and complex response of drainage systems. (In Morisawa, M.E., ed. Fluvial geomorphology. London, George Allen and Unwin, p. 299-310.)

Shaw, J. 1977[a]. Till body morphology and structure related to glacier flow. Boreas, Vol. 6, No. 2, p. 189-201.

Shaw, J. 1977[b]. Tills deposited in arid polar environments. Canadian Journal of Earth Sciences, Vol. 14, No. 6, p. 1239-45. 